\title{
Alleviation of salinity stress in white corn (Zea mays L.) plant by exogenous application of salicylic acid
}

\author{
Mona A. Ismail ${ }^{1,2}$ \\ ${ }^{1}$ Biotechnology Department, Faculty of Science, Taif University, Saudi Arabia \\ ${ }^{2}$ Botany Department, Faculty of Science, Suez Canal University, Egypt
}

\section{Email address:}

mool20002003@yahoo.com

\section{To cite this article:}

Mona A. Ismail. Alleviation of Salinity Stress in White Corn (Zea mays L.) Plant by Exogenous Application of Salicylic Acid. American Journal of Life Sciences. Vol. 1, No. 6, 2013, pp. 248-255. doi: 10.11648/j.ajls.20130106.12

\begin{abstract}
This experiment was conducted to study the effect of exogenous application of Salicylic Acid ( $200 \mathrm{ppm}$ ) to alleviate the damage in Zea mays L. plants under different $\mathrm{NaCl}$ doses $(20,40,60$ and $100 \mathrm{mMol})$. Shoot and root lengths, fresh and dry weights, leaf area, chlorophyll a, chlorophyll $\mathrm{b}$, total chlorophyll, chlorophyll stability index were measured. The antioxidant enzymes (lipid peroxidase and glutathione) activities were estimated. $\mathrm{NaCl}$ significantly $(P<0.05)$ reduced all measured growth parameters, photosynthetic efficiency and antioxidant oxidative enzyme contents. Exogenous application of SA alleviated the inhibitory effects of $\mathrm{NaCl}$ on Zea Mays plants. SA enhanced plant salt tolerance in terms of improving the measured plant growth criteria. Moreover, the antioxidant enzyme contents were enhanced in response to $\mathrm{NaCl}$ and/or SA treatment providing s synergistic interaction. The toxic effects generated by the lower concentration of $\mathrm{NaCl}$ $(20 \mathrm{mM})$ were completely overcome by the application of SA .SA ameliorated the stress generated by $\mathrm{NaCl}$ through the antioxidant system and the stability of the photosynthetic process.
\end{abstract}

Keywords: Zea Mays, Salinity, Salicylic Acid, Photosynthesis, Growth, Glutathione, Lipid Peroxidase

\section{Introduction}

Soil salinity is one of the most limiting environmental factors for crop production and it adversely affects the growth and productivity of many crops. It is estimated that at least $20 \%$ of total irrigated lands in the world is salt-affected (Pitman and Läuchli, 2002). Halophytes are reported to keep the cellular levels of these potentially damaging ROS within a narrow, functionally important range under optimum growing conditions by utilizing a coordinated antioxidant system consisting of enzymes like superoxide dismutases (SOD), catalases (CAT) and peroxidases (POD) and non-enzymatic antioxidants like ascorbate (ASA) and glutathione (GSH) (Jithesh, et al. 2006; Shabala, and Mackay, 2011). Therefore, at the whole plant level, a strong antioxidant defense system along with efficient ion regulation, production of compatible solutes and the maintenance of photosynthesis is attributed to salt tolerance in halophytes (Flowers and Colmer, 2008; Guan et al., 2011; Jithesh et al., 2006; Shabala and Mackaym, 2011; Song et al., 2006). However, these defense mechanisms would become inadequate under high saline conditions leading to growth inhibition and/or death (Flowers and Colmer, 2008; Jithesh et al., 2006; Munns and Tester, 2008). High salinity levels caused significant reduction in growth parameters like leaf area, leaf length, root and shoot dry weights (Ashrafuzzaman et al., 2002) .

The applications of plant growth regulators are found to play an important role in plant responses to stress (Chakrabarti and Mukherjee, 2003). Salicylic acid (SA) (2-hydroxybenzoic acid) is a plant phenolic compound and now considered as a hormone-like endogenous regulator (Fig.1). It plays important roles to defend plants against both biotic and abiotic stress conditions. It plays diverse physiological roles in, plants, which include plant growth, thermogenesis, flower induction, nutrient uptake, ethylene biosynthesis, stomatal movements, photosynthesis and enzyme activities (Hayat and Ahmad, 2007). Disease resistance is an additional role assigned to SA (Janda et al., 2007). Earlier reports showed that SA played important regulatory roles in plants against to a wide range of oxidative stresses (Choudhury \& Panda, 2004; Deef, 2007). Exogenous applications of SA enhanced plant growth and photosynthetic capacity in saline conditions (Khan et al., 2012; Afzal et al., 2006; Arfan et al., 2007; Arfan, 2009). 
There is also evidence that SA can alter the antioxidant capacity in plants (Chen et al., 1997; Rao et al., 1997). It has been reported that $\mathrm{SA}$ improves salinity tolerance by increasing antioxidant enzymes activities like SOD, POD and CAT activity (Noreen et al., 2009).

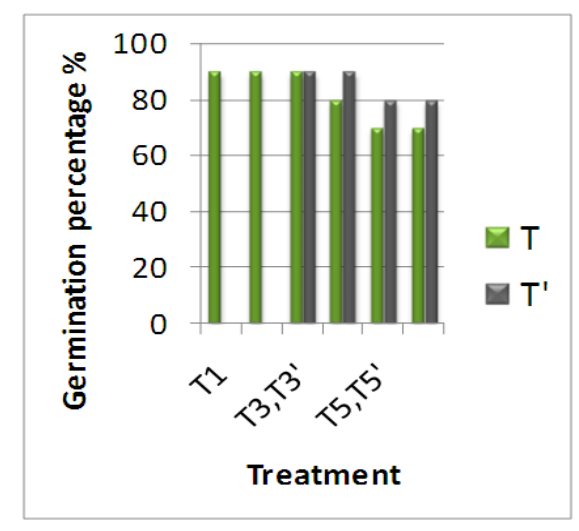

Figure 1. Germination percentage of white corn (Zea mays L.) plants subjected to $T 1, T 2, T 3, T 3^{\prime}, T 4, T 4^{\prime}, T 5, T 5^{\prime}$ ' and T6,T6').

$\mathrm{T} 1=$ untreated $($ control) plants, $\mathrm{T} 2=\mathrm{SA}$ Treated plants and T 3,T4T,T5,T6= plants treated with $20 \mathrm{Mmol} \mathrm{NaCl}, 40 \mathrm{Mmol} \mathrm{NaCl}, 60 \mathrm{Mmol} \mathrm{NaCl}$ and 100 $\mathrm{Mmol} \mathrm{NaCl}$, respectively.

After wheat and rice, Maize (Zea mays L.) plant is the third most important cereal crop in the world. Maize is grown all over the world in a wide range of climatic condition. Being highly cross pollinated, maize has become highly polymorphic through the course of natural and domesticated evolution and thus contains enormous variability (Paterniani, 1990) in which salinity tolerance may exist. Maize is moderately sensitive to salinity and is considered as salt-sensitive cereal (Mass \& Hofffman, 1977). Because of the great sensitivity of this crop to salt stress, improvement for salt tolerance would be of considerable value.

Accordingly, the present study was designed to verify the effect of the exogenous application of salicylic acid on improving growth and photosynthesis in Zea mays L. plants subjected to salt $(\mathrm{NaCl})$ stress, with a special emphasis on the activities of some antioxidant enzymes.

\section{Materials and Methods}

\subsection{Plant Materials and Experimental Design}

The experiment was conducted during the spring-summer of 2013. In the botanical garden of the faculty of science, Taif University, Saudi Arabia. A homogenous lot of seeds of Zea mays L. (hybrid 310) were obtained from the Crop Institute, Agricultural Research Center, Giza, Egypt. Seeds were surface-sterilized with sodium hypochlorite solution (5\%) for five minutes, then washed thoroughly with distilled water before use. Ten seeds were sown in black plastic pots, each filled with about $5 \mathrm{~kg}$ sandy soil. All planted pots were kept in the open garden in about $31 / 22{ }^{\circ} \mathrm{C}$ day/night temperature and average relative humidity $60 \%$. Pots were randomly subdivided to two equal groups, one group was subjected five treatment of $\mathrm{NaCl}(0,20,40,60,100 \mathrm{mM})$ and the other group was subjected to the same $\mathrm{NaCl}$ concentration $+200 \mathrm{ppm} \mathrm{SA}$. Each treatment was replicated 3 times in a split plot design. Plants were kept irrigated with half Hoagland nutrient solution of a $\mathrm{pH}$ 6-7 (Hoagland and Arnon, 1950). After one week, treatments ( $\mathrm{NaCl}$ and/or SA) were applied to corn plants in Hoagland medium for 4 weeks (Gunes et al., 2007).

\section{Measurements}

\subsection{Germination Percentage}

The number of germinated seeds in each treatment was recorded. The germination percentage was estimated using the following equation.

$$
\mathrm{GP}=\left(\frac{\mathrm{N}^{2}}{\mathrm{~N}}\right) \times 100
$$

Where, $\mathrm{N} \square$ is the number of germinated seeds and $\mathrm{N}$ is the number of used seeds in each pot.

\subsection{Growth Parameters}

\subsubsection{Plant Biomass (g)}

After 7 weeks from sowing, plants were smoothly uprooted and the root system was washed under running tap water. Data of the fresh biomass (plant height, shoot and root lengths, shoot and root fresh weights) were measured. Plants were oven-dried at $65{ }^{\circ} \mathrm{C}$ for 24 hours and the dry mass of shoot and root was estimated.

\subsubsection{Leaf Area $\left(\mathrm{cm}^{2}\right)$}

The Leaf area was determined following the formula of Carleton and Foote (1965) :

Leaf area $\left(\mathrm{cm}^{2}\right)=$ maximum leaf length $\mathrm{x}$ maximum leaf width $\mathrm{x} 0.75$

Where, $0.75=$ Correction factor.

\subsection{Biochemical Analysis}

\subsubsection{Chlorophyll Contents}

The contents of chlorophyll a and chlorophyll b were estimated according to the method described by Witham et al. (1971). The fresh leaves were cut into $0.5 \mathrm{~cm}$ segments and extracted overnight with $80 \%$ acetone at $-10^{\circ} \mathrm{C}$. The extract was centrifuged at $14000 \mathrm{xg}$ for $5 \mathrm{~min}$. and the absorbance of the supernatant was read at 645 and $663 \mathrm{~nm}$ using a spectrophotometer (IRMECO U2020). The contents (mg $\left.g^{-1} \mathrm{f} w \mathrm{w}\right)$

Chlorophyll a, chlorophyll b and total chlorophyll were calculated as follows:

$$
\begin{aligned}
& \text { Chl. } a=\left[1 2 . 7 \left(\text { A 663) }-2.69(\text { A 645) }] \times \frac{V}{1000 \times W}\right.\right. \\
& \text { Chl.b }=[22.9(A 645)-4.68(A 663)] \times \frac{V}{1000 \times W} \\
& \text { lotal Chl. }=[20.2(\mathrm{~A} 645)-8.02(\mathrm{~A} 663)] \times \frac{\mathrm{V}}{1000 \times \mathrm{W}}
\end{aligned}
$$


$A=$ absorbance at specific wavelengths.

$\mathrm{V}=$ volume of the extract $(\mathrm{ml})$.

$\mathrm{W}=$ weight of the fresh leaf tissue $(\mathrm{g})$.

\subsubsection{Chlorophyll Stability Index (CSI\%)}

Chlorophyll stability index (CSI\%) was calculated using the total chlorophyll contents in Zea mays L. leaves before and after salinity stress following the formula noted by kumara et al., (2004) :

$$
\text { CSI\% }=\frac{\text { chloraphyll hefore stress }- \text { chlorophyll after stress }}{\text { chlorophyll under stress }} \times 100
$$

\subsubsection{Statistical Analysis}

Data were statistically analyzed by multiple comparison procedure at $(P \leq 0.05)$ using t-test and mean separation by least significant difference (LSD) (steal and torri1,1980).

\subsection{Antioxidant and Oxidative Enzymes}

\subsubsection{Estimation of Antioxidant Enzymes}

The leaf tissue $(0.5 \mathrm{~g})$ was homogenized in some $\mathrm{M}$ phosphate buffer ( $\mathrm{pH}$ 7.0) containing 1\% (w/v) soluble polyvinyl pyrrolidone. The homogenate was atcentrifuged at $15000 \mathrm{~g}$ for $10 \mathrm{~min}$ at $4{ }^{\circ} \mathrm{C}$ and the supernatant (source of enzymes) was assayed following the procedure described by Chance and Maehly (1955) .

\subsection{Glutathione Peroxidase (GPX)}

\subsubsection{Assay of Glutathione Reductase (GR) Activities}

Total GR activity was assayed by a modified method of that described by Foyer and Halliwell (1976). The reaction mixture $(1.0 \mathrm{ml})$ consisted of $100 \mathrm{mM}$ phosphate (buffer $\mathrm{pH}$ 7.8), $0.1 \mu \mathrm{M}$ EDTA, $0.05 \mathrm{mM}$ NADPH, $3.0 \mathrm{mM}$ oxidized glutathione (GSSG) and $50 \mu \mathrm{L}$ enzyme extract. The reaction was started by the addition of GSSG and the NADPH oxidation rate was monitored at $340 \mathrm{~nm}$ for $1 \mathrm{~min}$. Enzyme activity was determined using the molar extinction coefficient for NADPH $\left(6.2 \mathrm{mM}^{-1} \mathrm{~cm}^{-1}\right)$ and expressed as $\mu \mathrm{mol}$ NADPH $\mathrm{min}^{-1} \mathrm{mg}^{-1} \mathrm{DM}$.

\subsubsection{Assay of Lipid Peroxidation}

Lipid peroxidation was determined using the thiobarbituric acid (TBA) reaction followed by measurement of MDA content (Heath and Packer, 1968). Tissues $(100 \mathrm{mg})$ were ground in $2 \mathrm{ml}$ of $25 \%$ TBA prepared in $10 \%$ TCA solution. The mixture was incubated at $95^{\circ} \mathrm{C}$ for $30 \mathrm{~min}$, cooled in an ice bath, and then centrifuged at $10000 \mathrm{xg}$ for $15 \mathrm{~min}$. The absorbance of the supernatant was measured at $532 \mathrm{~nm}$ and non-specific absorbance was measured at $600 \mathrm{~nm}$. The MDA concentration was defined by its extinction coefficient of $155 \mathrm{mM}^{-1} \mathrm{~cm}^{-1}$.

\section{Results}

\subsection{Germination Percentage}

In this experiment, seed germination $\%$ of decreased at $\mathrm{NaCl}$ concentrations higher than $20 \mathrm{mM}$ compared to the control (pure water). Application of SA significantly enhanced seed germination under $\mathrm{NaCl}$ stress higher than 20 $\mathrm{mM}$ (Figure1).

\subsection{Growth Parameters}

\subsubsection{Plant Biomass (g)}

$\mathrm{NaCl}$ salt stress caused inhibition of shoot and root growth, reduction in the fresh and dry weights of shoots and roots, minimized leaf area in Zea mays L. plant. However, the synergistic interaction of salinity and salicylic acid resulted in enhanced plant growth (Figure2,3,4).
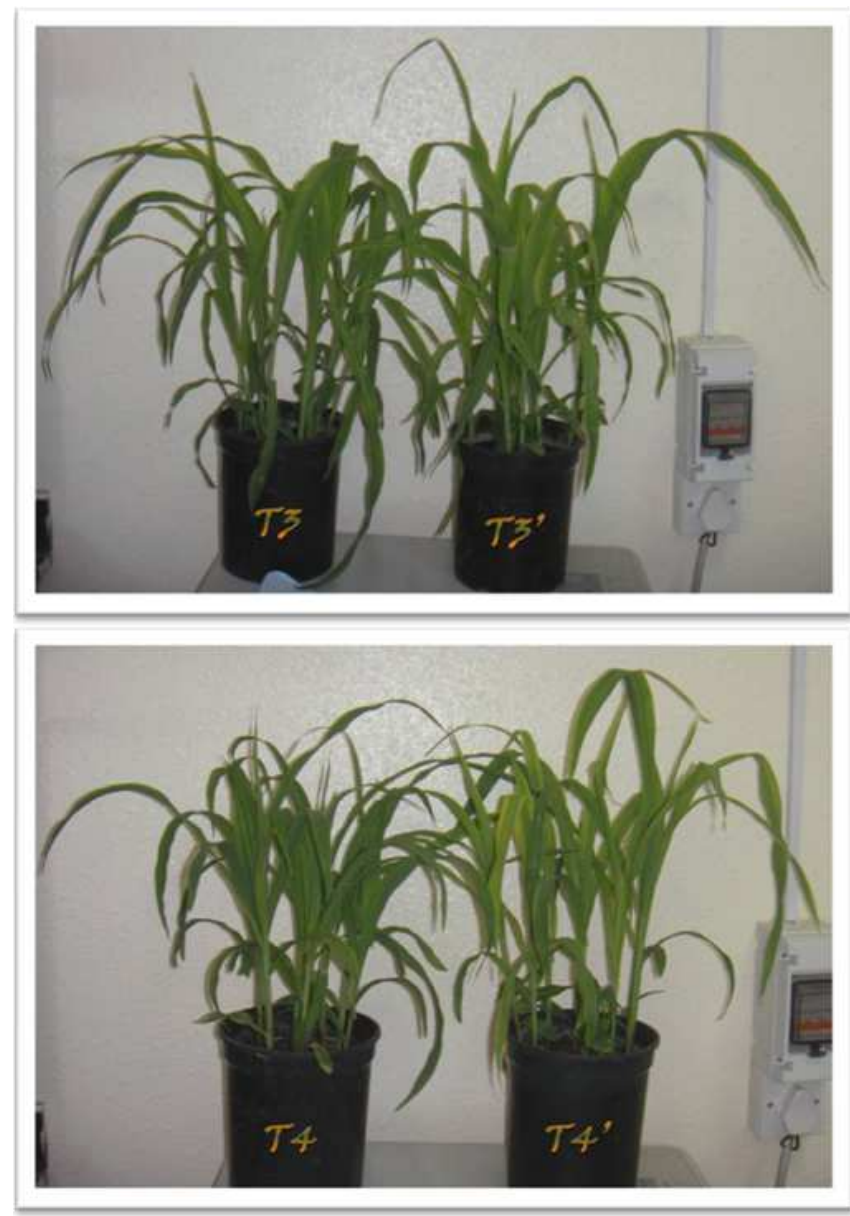

Figure 2. Morphology of white corn Zea mays L. plants subjected to, T3,T3' and T4,T4').

T 3,T4T,T5,T6 = plants treated with $20 \mathrm{mmol} \mathrm{NaCl}$ and $40 \mathrm{mmol} \mathrm{NaCl}$, respectively.

While T3', T4' = plants treated with $20 \mathrm{mmol} \mathrm{NaCl}+200 \mathrm{ppm}$ salicylic acid and $40 \mathrm{mmol} \mathrm{NaCl}+200 \mathrm{ppm}$ salicylic acid, respectively .

\subsubsection{Fresh Biomass and Dry Mass}

The results in figure 3 ( $a$ and $b$ ) indicated declines in plant growth. Both root and shoot fresh and dry weights decreased dramatically in salt stressed plant. After SA treatment, corn plants showed higher fresh and dry weight compared to control (plants without application of SA under salinity condition (Figure, $a$ and $b$ ). 


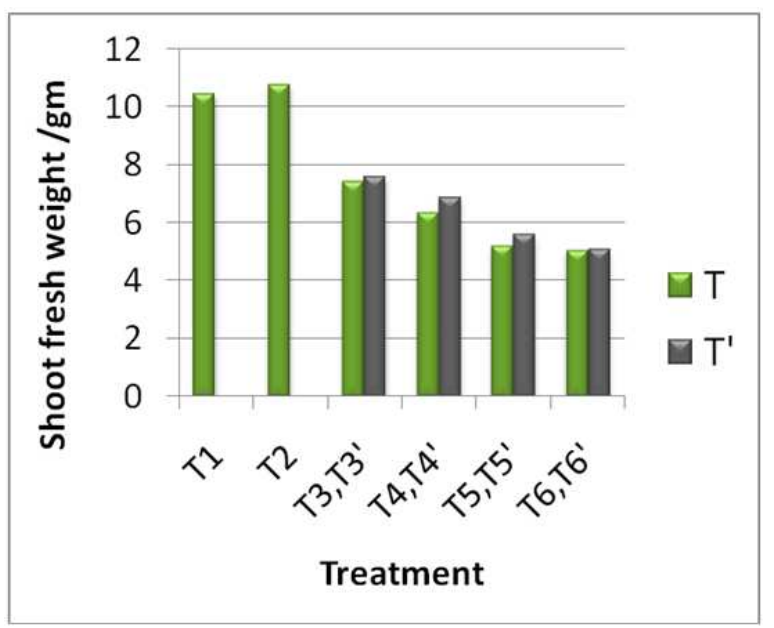

Figure3,a : Shoot fresh and dry weight of white corn Zea mays L. plants subjected to $T 1, T 2, T 3, T 33^{\prime}, T 4, T 4{ }^{\prime}, T 5, T 5^{\prime}$ ' and $\left.T 6, T 6^{\prime}\right)$.

$\mathrm{T} 1=$ untreated (control) plants, T2 $=$ SA Treated plants and T 3,T4T,T5,T6 = plants treated with $20 \mathrm{mmol} \mathrm{NaCl}, 40 \mathrm{mmol} \mathrm{NaCl}, 60 \mathrm{mmol} \mathrm{NaCl}$ and $100 \mathrm{mmol} \mathrm{NaCl}$, respectively.

While T3', T4', T5', and T6' = plants treated with $20 \mathrm{Mmol} \mathrm{NaCl}+200$ ppm salicylic acid , $40 \mathrm{Mmol} \mathrm{NaCl}+200 \mathrm{ppm}$ salicylic acid, $60 \mathrm{mmol} \mathrm{NaCl}$ $+200 \mathrm{ppm}$ salicylic acid and $100 \mathrm{Mmol} \mathrm{NaCl}+200 \mathrm{ppm}$ salicylic acid, respectively .

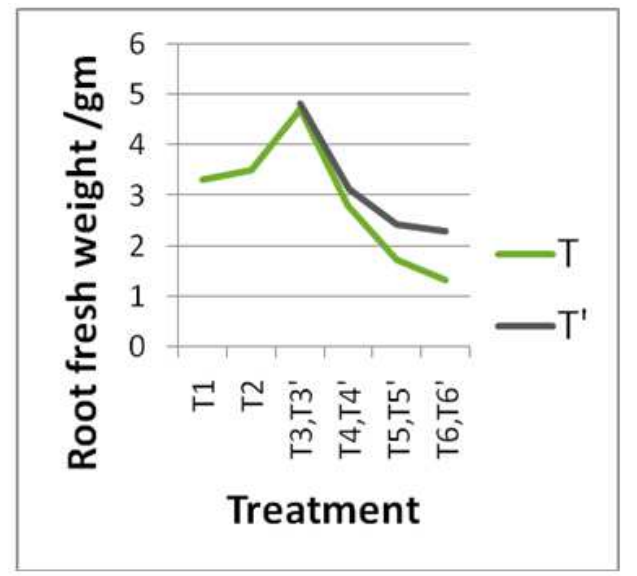

Figure 3b. Root fresh weight (left) and root dry weight(right) of white corn (Zea mays L.) plants subjected to T1,T2,T3,T3',T4,T4',T5,T5' and T6,T6').

$\mathrm{T} 1=$ untreated (control) plants, T2 $=$ SA Treated plants and T 3,T4T,T5,T6 = plants treated with $20 \mathrm{mmol} \mathrm{NaCl}, 40 \mathrm{mmol} \mathrm{NaCl}, 60 \mathrm{mmol} \mathrm{NaCl}$ and $100 \mathrm{mmol} \mathrm{NaCl}$, respectively.

While T3', T4', T5', and T6'= plants treated with $20 \mathrm{mmol} \mathrm{NaCl}+200 \mathrm{ppm}$ salicylic acid , $40 \mathrm{mmol} \mathrm{NaCl}+200 \mathrm{ppm}$ salicylic acid, $60 \mathrm{mmol} \mathrm{NaCl}+$ $200 \mathrm{ppm}$ salicylic acid and $100 \mathrm{mmol} \mathrm{NaCl}+200 \mathrm{ppm}$ salicylic acid, respectively.

\subsubsection{Shoot, Root Lengths and Plant Height}

$\mathrm{NaCl}$ and SA applications had a significant effect on plant height. Shoot and root lengths decreased. Salt $(\mathrm{NaCl})$ stress reduced plant height, this reduction of plant height increased gradually with increasing of $\mathrm{NaCl}$ concentration. Application of SA increased significantly the Shoot and root lengths (Figure 4, a and b).

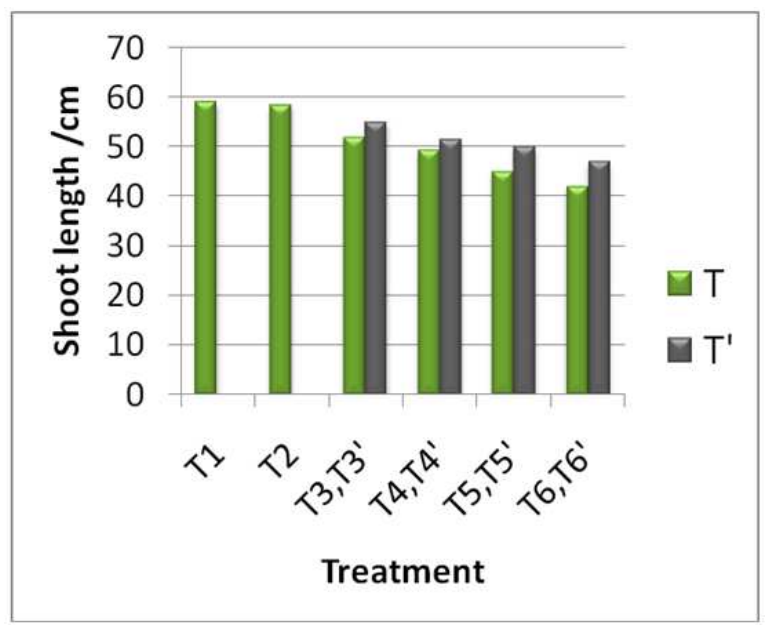

Figure 4a. Shoot length of white corn (Zea mays L.) plants subjected to T1,T2,T3,T3',T4,T4',T5,T5' and T6,T6').

$\mathrm{T} 1$ = untreated (control) plants, T2 = SA Treated plants and T 3,T4T,T5,T6 = plants treated with $20 \mathrm{mmol} \mathrm{NaCl}, 40 \mathrm{mmol} \mathrm{NaCl}, 60 \mathrm{mmol} \mathrm{NaCl}$ and $100 \mathrm{mmol} \mathrm{NaCl}$, respectively.

While T3', T4', T5', and T6'= plants treated with $20 \mathrm{mmol} \mathrm{NaCl}+200 \mathrm{ppm}$ salicylic acid , $40 \mathrm{mmol} \mathrm{NaCl}+200 \mathrm{ppm}$ salicylic acid, $60 \mathrm{mmol} \mathrm{NaCl}+$ $200 \mathrm{ppm}$ salicylic acid and $100 \mathrm{mmol} \mathrm{NaCl}+200 \mathrm{ppm}$ salicylic acid, respectively.

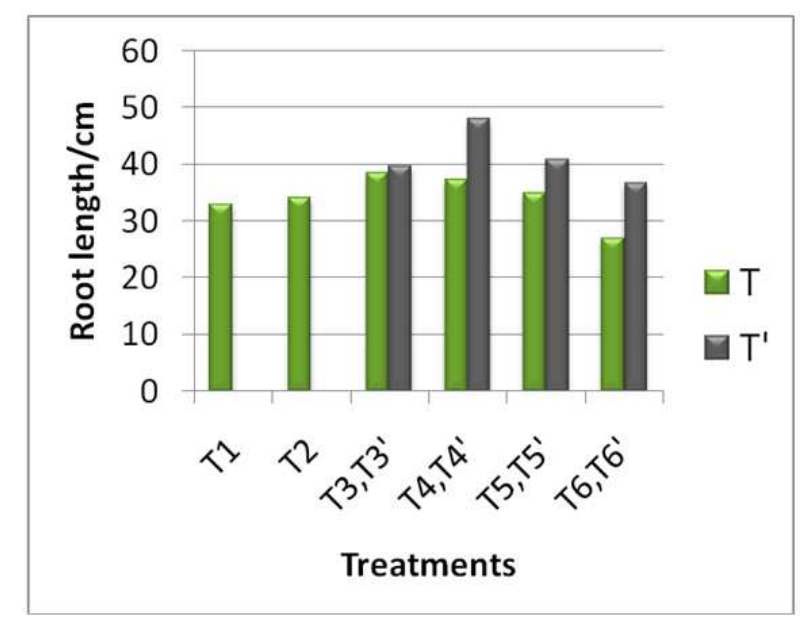

Figure $4 \boldsymbol{b}$. Root length of white corn Zea mays L. plants subjected to T1,T2,T3,T3',T4,T4',T5,T5' and T6,T6').

$\mathrm{T} 1=$ untreated (control) plants, T2 = SA Treated plants and T 3,T4T,T5,T6 = plants treated with $20 \mathrm{mmol} \mathrm{NaCl}, 40 \mathrm{mmol} \mathrm{NaCl}, 60 \mathrm{mmol} \mathrm{NaCl}$ and $100 \mathrm{mmol} \mathrm{NaCl}$, respectively.

While T3', T4', T5', and T6'= plants treated with $20 \mathrm{mmol} \mathrm{NaCl}+200 \mathrm{ppm}$ salicylic acid , $40 \mathrm{mmol} \mathrm{NaCl}+200 \mathrm{ppm}$ salicylic acid, $60 \mathrm{mmol} \mathrm{NaCl}+$ $200 \mathrm{ppm}$ salicylic acid and $100 \mathrm{mmol} \mathrm{NaCl}+200 \mathrm{ppm}$ salicylic acid, Respectively

\subsubsection{Leaf Area $\left(\mathrm{cm}^{2}\right)$}

Leaf area was negatively affected with salinity stress, while SA treatment resulted in increased leaf area. The highest value of leaf area was determined in $0 \mathrm{mM} \mathrm{NaCl}$ (control) and the lowest leaf area was obtained at $100 \mathrm{mM}$ $\mathrm{NaCl}$ ( Figure5). 


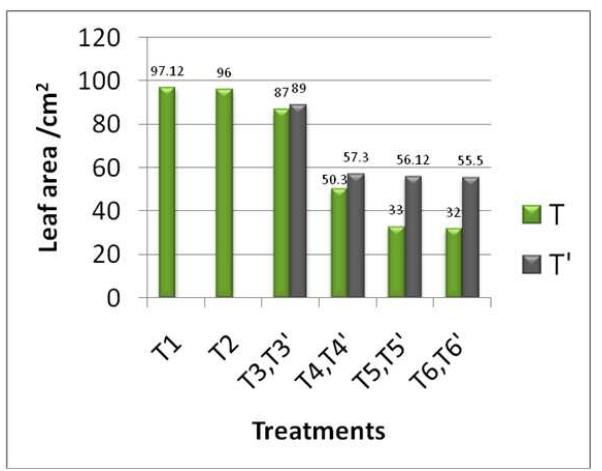

Figure 5. Leaf area of white corn Zea mays L. plants subjected to $T 1, T 2, T 3, T 3^{\prime}, T 4, T 4^{\prime}, T 5, T 5^{\prime}$ ' and $T 6, T 6^{\prime}{ }^{\prime}$.

$\mathrm{T} 1=$ untreated $($ control) plants, $\mathrm{T} 2=\mathrm{SA}$ Treated plants and $\mathrm{T} 3, \mathrm{~T} 4 \mathrm{~T}, \mathrm{~T} 5, \mathrm{~T} 6=$ plants treated with $20 \mathrm{mmol} \mathrm{NaCl}, 40 \mathrm{mmol} \mathrm{NaCl}, 60 \mathrm{mmol} \mathrm{NaCl}$ and 100 mmol NaCl, respectively.

While T3', T4', T5', and T6' $=$ plants treated with $20 \mathrm{mmol} \mathrm{NaCl}+200 \mathrm{ppm}$ salicylic acid , $40 \mathrm{mmol} \mathrm{NaCl}+200 \mathrm{ppm}$ salicylic acid, $60 \mathrm{mmol} \mathrm{NaCl}+$ $200 \mathrm{ppm}$ salicylic acid and $100 \mathrm{mmol} \mathrm{NaCl}+200 \mathrm{ppm}$ salicylic acid, respectively

\subsubsection{Photosynthesis Pigments}

Increased salinity levels $(20,40,60$ and $100 \mathrm{mM} \mathrm{NaCl})$ resulted in a sharp decline in the total pigment content of Zea mays leaves. Such reduction was attributed to the decline in the chlorophyll a \& chlorophyll b contents (Figure 6). The highest reduction in photosynthetic pigments was displayed at the highest salinity level (100 $\mathrm{mM} \mathrm{NaCl}$ ).. Application of SA, in most cases, did not only alleviate the inhibitory effect of salinity stress on the biosynthesis of photosynthetic pigments, but also induced a significant stimulatory effect greater than observed in the corresponding control. This response may be attributed directly to the efficiency of photosynthetic apparatus that alter plant productivity. photosynthetic pigment was affected under salinity stress and addition of salicylic acid to plant medium remarkably increased the photosynthetic pigments (Figure 6a). SA increased seedling survival under treatment with $\mathrm{NaCl}$ ( Figure 6b).

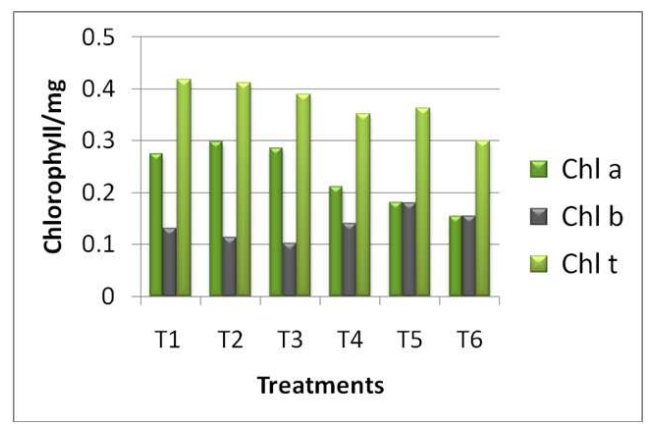

Figure 6a. Chlorophyll amounts of white corn Zea mays L. plants subjected to T1,T2,T3, T4,T5 and T6).

$\mathrm{T} 1=$ untreated (control) plants, $\mathrm{T} 2=\mathrm{SA}$ Treated plants and $\mathrm{T} 3, \mathrm{~T} 4 \mathrm{~T}, \mathrm{~T} 5, \mathrm{~T} 6=$ plants treated with $20 \mathrm{mmol} \mathrm{NaCl}, 40 \mathrm{mmol} \mathrm{NaCl}, 60 \mathrm{mmol} \mathrm{NaCl}$ and 100 mmol NaCl, respectively.

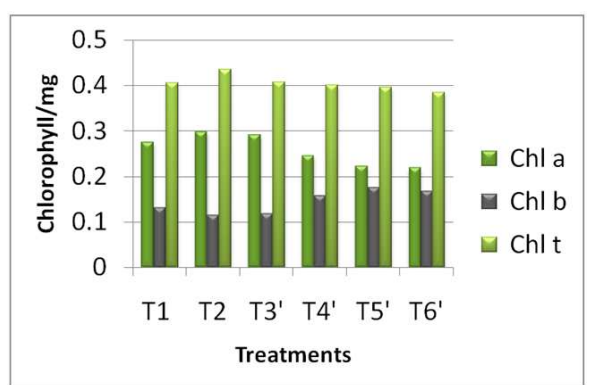

Figure 6b. Chlorophyll amounts of white corn Zea mays L. plants subjected to $T 1, T 2, T 3^{\prime}, T 4^{\prime}, T 5^{\prime}$ and $T 6^{\prime}$ ').

$\mathrm{T} 1=$ untreated (control) plants, $\mathrm{T} 2=\mathrm{SA}$ Treated plants and T3', T4', T5', and $\mathrm{T}^{\prime}=$ plants treated with $20 \mathrm{mmol} \mathrm{NaCl}+200 \mathrm{ppm}$ salicylic acid , 40 mmol NaCl+200 ppm salicylic acid, $60 \mathrm{mmol} \mathrm{NaCl}+200 \mathrm{ppm}$ salicylic acid and $100 \mathrm{mmol} \mathrm{NaCl}+200 \mathrm{ppm}$ salicylic acid, respectively

\subsection{Chlorophyll Contents}

The spectrophotometric estimation of chlorophyll pigments indicated inhibition of total cholorophyll content at high $\mathrm{NaCl}$ concentration. This inhibition was recovered by the addition of $200 \mathrm{ppm}$ salicylic acid ( Figure7). On other hand, the value of chlorophyll stability index (CIS\%) was higher in response to a combination of $\mathrm{NaCl}$ and SA. ( Figure8).

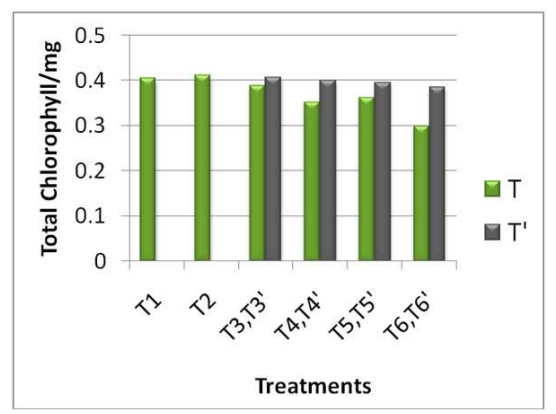

Figure 7. Total chlorophyll content of white corn Zea mays L. plants subjected to T1,T2,T3,T3 ',T4,T4',T5,T5' and T6,T6').

$\mathrm{T} 1=$ untreated $($ control) plants, $\mathrm{T} 2=\mathrm{SA}$ Treated plants and T 3,T4T,T5,T6 = plants treated with $20 \mathrm{mmol} \mathrm{NaCl}, 40 \mathrm{mmol} \mathrm{NaCl}, 60 \mathrm{mmol} \mathrm{NaCl}$ and 100 mmol NaCl, respectively.

While T3', T4', T5', and T6'= plants treated with $20 \mathrm{mmol} \mathrm{NaCl}+200 \mathrm{ppm}$ salicylic acid , $40 \mathrm{mmol} \mathrm{NaCl}+200 \mathrm{ppm}$ salicylic acid, $60 \mathrm{mmol} \mathrm{NaCl}+$ $200 \mathrm{ppm}$ salicylic acid and $100 \mathrm{mmol} \mathrm{NaCl}+200 \mathrm{ppm}$ salicylic acid, respectively

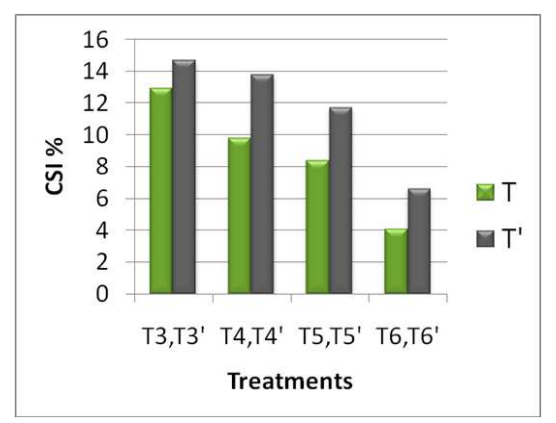

Figure 8. Chlorophyll stability index (CSI\%) of white corn Zea mays L. plants subjected to T1,T2,T3,T3 ',T4,T4',T5,T5' and T6,T6'). 
$\mathrm{T} 1=$ untreated $($ control) plants, $\mathrm{T} 2=\mathrm{SA}$ Treated plants and $\mathrm{T} 3, \mathrm{~T} 4 \mathrm{~T}, \mathrm{~T} 5, \mathrm{~T} 6=$ plants treated with $20 \mathrm{mmol} \mathrm{NaCl}, 40 \mathrm{mmol} \mathrm{NaCl}, 60 \mathrm{mmol} \mathrm{NaCl}$ and 100 $\mathrm{mmol} \mathrm{NaCl}$, respectively.

While T3', T4', T5', and T6' $=$ plants treated with $20 \mathrm{mmol} \mathrm{NaCl}+200 \mathrm{ppm}$ salicylic acid , $40 \mathrm{mmol} \mathrm{NaCl}+200 \mathrm{ppm}$ salicylic acid, $60 \mathrm{mmol} \mathrm{NaCl}+$ $200 \mathrm{ppm}$ salicylic acid and $100 \mathrm{mmol} \mathrm{NaCl}+200 \mathrm{ppm}$ salicylic acid, respectively .

\subsection{Antioxidant and Oxidative Enzymes}

\subsubsection{Lipid per Oxidation}

The effect of salt stress on the activity of lipid peroxidase was studied in Zea mays L. plants grown under salt stress (nutrient solution contining $\mathrm{NaCl}$ ) and Salt stress $+\mathrm{SA}$ (nutrient solution contining $\mathrm{NaCl}+\mathrm{SA}$ ). The results (Figure 9) showed that lipid peroxidase was enhanced only in salt-stressed plants, compared to corn plants treated with salt stress + SA. Progressive increases in lipid peroxidation under severe salt stress $(100 \mathrm{mM})$ were partially inhibited by exogenous salicylic acid. Salt stress increased the accumulation of lipid peroxidation products produced by the action of damaging reactive oxygen species (ROS) of salt stress. Addition of salicylic acid hindered the accumulation of lipid peroxidase produced under salt stresss.

As a consequence of the induced cellular build up of reactive oxygen species (ROS) under salt stress is the increase in lipid peroxidation products in the form of thiobarbituric and reactive substances (TBARS ). Salt stress induced progressive accumulation of TBARS in the plant tissues of the salt stressed corn plants. Exogenous salicylic acid partially inhibited these increases of lipid peroxidation products ( Fig.9).

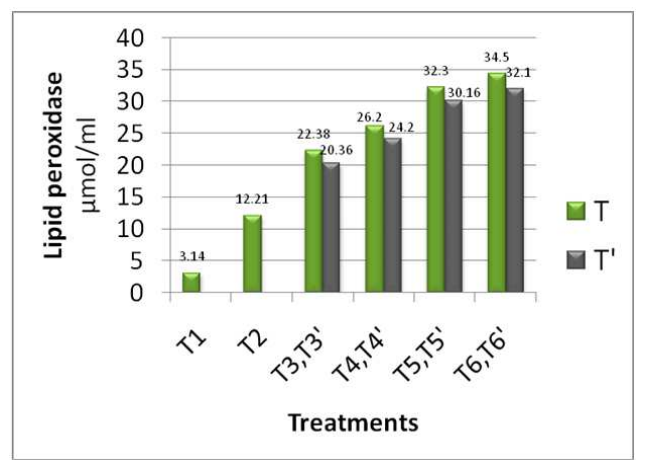

Figure 9. Lipid peroxidase content of white corn Zea mays L. plants subjected to T1,T2,T3,T3',T4,T4',T5,T5' and T6,T6').

$\mathrm{T} 1=$ untreated $($ control) plants, $\mathrm{T} 2=\mathrm{SA}$ Treated plants and T 3,T4T,T5,T6= plants treated with $20 \mathrm{mmol} \mathrm{NaCl}, 40 \mathrm{mmol} \mathrm{NaCl}, 60 \mathrm{mmol} \mathrm{NaCl}$ and 100 mmol NaCl, respectively.

While T3', T4', T5', and T6'= plants treated with $20 \mathrm{mmol} \mathrm{NaCl}+200 \mathrm{ppm}$ salicylic acid , $40 \mathrm{mmol} \mathrm{NaCl}+200 \mathrm{ppm}$ salicylic acid, $60 \mathrm{mmol} \mathrm{NaCl}+$ $200 \mathrm{ppm}$ salicylic acid and $100 \mathrm{mmol} \mathrm{NaCl}+200 \mathrm{ppm}$ salicylic acid, respectively .

\subsubsection{Non-Enzymatic Antioxidation}

The activity of the non-enzymatic antioxidant increased in response to $\mathrm{NaCl}$ stress treatments in the presence or absence of SA ( Figure10). Antioxidants such as glutathione, which was found in cellular compartments, are crucial for plant defense against oxidative stress. Stressed Zea mays L. plant exhibited elevated levels of glutathione ( Figure 10). The salt $(\mathrm{NaCl})$ treatment enhanced the glutathione activities which were elevated to higher extent by the application of SA to salt stressed corn plants. The results postulate that glutathione may have important function in the stress responses due to its role in detoxification of toxic stress metabolites, e. g lipid peroxide, so preventing the membrane damages.

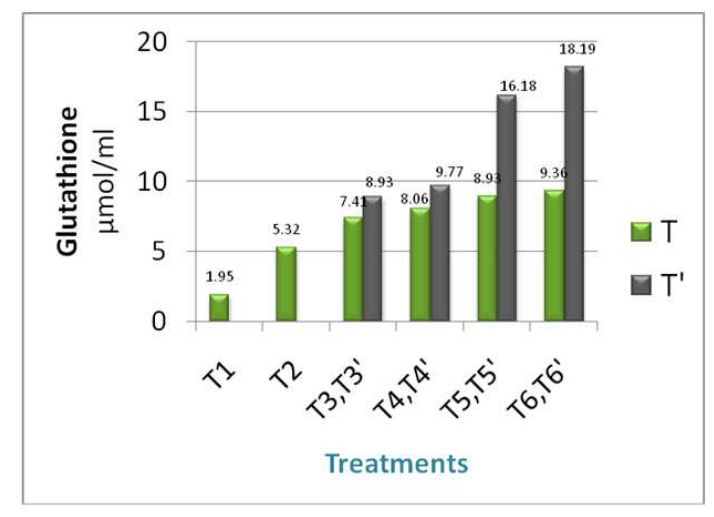

Figure 10. Glutathione content of white corn Zea mays L. plants subjected to $T 1, T 2, T 3, T 3$ ', T4,T4',T5,T5' and T6,T6').

$\mathrm{T} 1=$ untreated $($ control) plants, $\mathrm{T} 2=\mathrm{SA}$ Treated plants and T 3,T4T,T5,T6 = plants treated with $20 \mathrm{mmol} \mathrm{NaCl}, 40 \mathrm{mmol} \mathrm{NaCl}, 60 \mathrm{mmol} \mathrm{NaCl}$ and 100 mmol NaCl, respectively.

While T3', T4', T5', and T6'= plants treated with $20 \mathrm{mmol} \mathrm{NaCl}+200 \mathrm{ppm}$ salicylic acid , $40 \mathrm{mmol} \mathrm{NaCl}+200 \mathrm{ppm}$ salicylic acid, $60 \mathrm{mmol} \mathrm{NaCl}+$ $200 \mathrm{ppm}$ salicylic acid and $100 \mathrm{mmol} \mathrm{NaCl}+200 \mathrm{ppm}$ salicylic acid, respectively .

Our results indicate that the increase glutathione enzyme activates with diverse functions may partially participate in the hardening effect of SA and increase the salt stress tolerance of Zea mays L. plant in a complicated way. Moreover, salicylic acid decreased the lipid peroxidation (MDA) and stimulated the glutathione (GSH) as antioxidant defense compounds. Therefore, treatment with SA alleviated the adverse effect of salinity stress.

\section{Discussion}

In the present investigation, the responses of Zea mays L. plant to high level of salinity were reflected by reduction of shoot and root fresh and dry weights. The stressful environment in the soil solution at concentrations 20, 40, 60 and $100 \mathrm{mM} \mathrm{NaCl}$ attenuated the fresh and dry matter gain in roots and shoots. The inhibitory affects of salt stress to growth parameters add more support to the ubiquitous finding in earlier investigation (Perez-Alfocea et a.l., 1993; Hamada, 1996). The reduced plant growth under salt stress conditions could be attributed to the physiological drought induced by the low water potential of soil solution and osmotic adjustment in plants as a result of increased ionic 
concentration in their cells, which result in deformation of macromolecules by disturbing their shell or bound water (Schwarz, 1985). Consequently, Soil salinity disrupts water uptake and ion equilibrium of plants, eventually leading to oxidative damage to membrane lipids, proteins and nucleic acids (Munns and Tester, 2008; Zhu, 2001).

The exogenous application of salicylic acid improved the fresh and dry weights of salt stressed Zea mays L. plants. Consistent finding reported on the beneficial effects of exogenous addition of salicylic acid in mitigating partially the adverse effects of salt stress on growth, like cell division, cell enlargement. High salt stress limits $\mathrm{CO}_{2}$ fixation resulting in over-reduced photosynthetic machinery, which accelerates the production of reactive oxygen species (ROS) hydrogen peroxide (Miller et al. 2010). Our result revealed significant synergistic effect between $\mathrm{NaCl}$ stress and exogenous SA on the chlorophyll contents and chlorophyll stability index (CSI\%) in leaves of Zea mays L. plants. These results are in a harmony with those observed by Hassanein (2000). The severe reduction in the photosynthetic pigments might be attributed to the toxic action of $\mathrm{NaCl}$ on the biosynthesis of pigments, increasing their degradation and/or maintaining damage of the chloroplast thylakoid (Rao,1981)

Since salt stress can lead to reactive oxygen species ( ROS) that may cause cellular damage, one of the proposed biochemical modes of salicylic acid is to acts as an antioxidant by scavenging hydrogen peroxide (chloroplast lack catalase) as it forms (Miyake and Asada, 1992). One of the important role of SA in inducing resistance to various environmental stress is manifested by its ability to express gene that code for PR-proteins (Merkour opoulos et al., 1999). Several studies also support a major role for SA in modulating the plant response to several abiotic stress (Yalpani et al., 1994, Senaratna et al., 2000). In maize plants, pre-treatment with SA induced antioxidant enzymes, which in turn increased chilling tolerance (Janda et al.,1999).Glutathione (GSH) is a multifunctional metabolite present in all organisms. In plant, it is present in the cystosol, plastids and mitochondria. GSH plays a pivotal role as antioxidant in prevention of cells against oxidative damage under a biotic or biotic stress by equilibrating the redox status (Noctor and Fayer 1998).

\section{Conclusion}

Salinity causes oxidative stress in white corn plants. Glutathione and lipid peroxidase enzymes appeared to have a pivotal role in combating oxidative stress in white corn plants. The increased activity of the involved enzymes in removing reactive oxygen species, like lipid peroxidase, resulted from the stimulation of gene expression to alleviate the adverse effects of oxidative stress caused by salinity stress. Salicylic acid derivatives which are found in the plants very commonly, and having hormone-like effect, can decrease the adverse effects of salinity stress, especially in low dose (200 ppm).

\section{Acknowledgments}

The authors are sincerely thanking anonymous reviewers for comments on earlier drafts of this manuscript. The authors are also grateful to Taif University.

\section{References}

[1] I. Afzal, S.M.A. Basra, M. Farooq and A. Nawaz (2006). Alleviation of salinity stress in spring wheat by hormonal priming with $\mathrm{ABA}$, salicylic acid and ascorbic acid. Int. J. Agri. Biol., 8: 23-28.

[2] M. Arfan, (2009). Exogenous application of salicylic acid through rooting medium modulates ion accumulation and antioxidant activity in spring wheat under salt stress. Int. J. Agri. Biol., 11: 437-442.

[3] M. Arfan, A. Habib and M. Ashraf.( 2007). Does exogenous application of salicylic acid through the rooting medium modulate growth and photosynthetic capacity in two differently adapted spring wheat cultivars under salt stress J. Plant Physiol., 164(6): 685-694.

[4] D. T. Arnon, (1994). Copper enzyme in isolated chloroplasts, polyphenaloxidase in Beta vulgaris. Plant Physiol., 24: 1-15.

[5] M. Ashrafuzzaman, M.A.H. Khan and S.M. Shahidullah, (2002). Vegetative growth of maize (Zea mays) as affected by a range of salinity. Crop Res. Hisar, 24: 286-91

[6] Carleton and Foote.( 1965). A comparison of methods for estimating total leaf area of barley plants. Crop Sci., 5(6): $602-603$

[7] N. Chakrabarti , S. Mukher Jee (2003) . Effect of phytohormones pre -treatment on nitrogen metabolism in vigno radiate under salt stress.Biol.plant. 36, 63-66.

[8] M. Chance, and A. C. Maehly. (1955). Assay of catalases and peroxidases. Methods Enzymol., 2:764-817.

[9] Z. Chen, S. Iyer, A. Caplan, D.F. Klessig and B. Fan. (1997). Differential accumulation of salicylic acid and salicylic acid-sensitive catalase in different rice tissues. Plant Physiol., 114: 193-201.

[10] S. Choudhury, \& S. K. Panda( 2004). Role of salicylic acid in regulating cadmium induced oxidative stress in Oryza sativa L. roots. Bulg. J. Plant Physiol., 30 (3-4), 95-110.

[11] H. E. Deef, (2007). Influence of salicylic acid on stress tolerance during seed germination of Triticum aestivum and Hordeum vulgare. Advances in Biological Research, 1 (1-2): 40-48.

[12] TJ. Flowers, TD. Colmer( 2008). Salinity tolerance in halophytes. New Phytol 179:945-963

[13] CH . Foyer, B . Halliwell (1976). The presence of glutathione and glutathione reductase in chloroplasts: a proposed role in ascorbate acid metabolism. Planta 133: 21-25

[14] B .Guan, Hu Y. Zeng, Y. Wang, F. Zhang (2011). Molecular characterization and functional analysis of a vacuolar $\mathrm{Na}+/ \mathrm{H}+$ antiporter gene (HcNHX1) from Halostachys caspica. Mol Biol Rep 38:1889-1899 
[15] A. Gunes., A. Inal , M. Alpaslan, , N. Cicek, E. Guneri , F..Eraslan, T. Guzelordu ( 2005). Effects of exogenously applied salicylic acid on the induction of multiple stress tolerance and mineral nutrition in maize (Zea mays L.). Arch. Agron. Soil Sci. 51, 687-695.

[16] Y. Gunes , A. Inal, M. Alpaslan, F. Eraslan, E.G. Bagci and G.N. Cicek (2007). Salicylic acid induced changes on some physiological parameters symptomatic for oxidative stress and mineral nutrition in maize (Zea mays L.) grown under salinity. J. of Plant Physiol.164:728-736

[17] AM . Hamada (1996). Effect of $\mathrm{NaCl}$, water stress or both on gas exchange and growth of wheat. Biol. Plant. 38: 405-412.

[18] A.A. Hassanein (2000). Physiological responses induced by shock and gradual salinization in rice (Oryza sativa L.) seedlings and the possible roles played by glutathione treatment. Acta Botanica Hungarica, 42(1-4): 139-159.

[19] S. Hayat, H. Ahmad (2007). Salicylic acid: A Plant Hormone. Springer, Dordrecht, The Netherlands

[20] RL. Heath, L. Packer (1968). Photoperoxidation in isolated chloroplasts: I. kinetics and stoichiometry of fatty acid peroxidation. Arch Biochem Biophys 125:189-198

[21] D.R.. Hoagland, and D.I Arnon (1950). The water culture method for growing plants without soil. California Agri. Exp. Stat. Circ., 347: 32

[22] T. Janda, E. Horvath, G. Szalai, E. .Paldi (2007). Role of salicylic acid in the induction of abiotic stress tolerance. In S. Hayat, A. Ahmad (eds.), hormone, Salicylic acid: A plant $(91-150)$. Springer, Dordrecht, The Netherlands.

[23] T. Janda, E. Horvath, G. Szalai, E. Paldi (1999). Hydroponic treatment with salicylic acid decrease the effects of chilling injury in maiz ( zea mays L. ) plants .planta, 208:175-180

[24] MN . Jithesh, SR. Prashanth, KR. Sivaprakash, AK. Parida (2006) Antioxidative response mechanisms in halophytes: their role in stress defence. J Genet 85:237-254

[25] S.U. Khan, A. Bano, J. Din and A.R. Gurmani. 2012. Abscisic acid and salicylic acid seed treatment as potent inducer of drought tolerance in wheat (Triticum aestivum L.). Pak. J. Bot., 44(1): 4349.

[26] M Kumari, MD sam, Y virnala, A. Pawan (2004). physiological parameters governing drought in maize. Indian J plant physiol.:203-207.

[27] J. D Maguire (1962) "Speed of Germination-Aid in Selection and Evaluation for Seedling Emergence and Vigor," Crop Science, Vol. 2, No. 2, , pp. 176-177.

[28] E.V. Mass, and G.J. Hoffman. (1977). Crop salt tolerance current assessment. J. Irrig. and Drain Div. ASCE 103: $115-134$

[29] G. Merkouropolous, D. C. Barnett, A. H. Shirasat (1999). The Arabidopsis expensin gene is developmentally regulated, is induced by wounding, methyl jasmonate, abscicissic acid, salicylic acid and codes for protein with unusual motifs. planta, 208,212-219

[30] G. Miller, N. Suzuki, S. Ciftci-Yilmaz, R. Mittler ( 2010). Reactive oxygen species homeostasis and signaling during drought and salinity stresses. Plant Cell Environ 33:453-467

[31] C. Miyake, K. Asada (1992). Thylakoid bound ascorbate peroxidase in Monodehydroascorbate radicals in the thylakoids. Plant Cell Physiol. 33: 541-553.

[32] R .Munns, M .Tester (2008). Mechanisms of salinity tolerance. Annu Rev Plant Biol 59:651-681

[33] G. Nector, CH. Foyer (1998). Ascorbate and glutathione,keeping active oxygen under .Annu Rev. Plant Physiol,Mol.Biol.4249-279

[34] S. Noreen, M. Ashraf, M. Hussain and A. Jamil.( 2009). Exogenous application of Salicylic acid enhances antioxidative capacity in salt stressed sunflower (Helianthus annus L.) plants. Pak. J. Bot., 41(1): 473-479.

[35] E. Paterniani, (1990). Maize breeding in tropics. Cri. Rev. Plant Sci., 9: 125-154.

[36] F. Pérez-Alfocea, MT . Estan, M. Caro, and G. Guerrier (1993). Osmotic adjustment in Lycopercon esculentum and L. pennelli under $\mathrm{NaCl}$ and polyethylene glycol 6000 iso-osmotic stress stresses. Physiol. Plant.87:493-498

[37] MG . Pitman, A . Läuchli (2002). Global impact of salinity and agricultural ecosystems. In: Läuchli A, Lüttge U (eds) Salinity: environment - plants - molecules. Kluwer, Dordrecht, pp 3-20 Plant. 87: 493-498

[38] G.G. Rao, and G.R. Rao,( 1981). Pigment composition and chlorophylase activity in pigeon pea (Cajanus indicus Sperng) and gingelley (Sesamum indicum $\mathrm{L}$ ) under $\mathrm{NaCl}$ salinity, Indian , J. Exp. Biol., 19: 768-770.

[39] G. Rao, P. Paliyath, D.P. Ormrod, C.B. Murr and Watkins (1997). Influence of salicylic acid on $\mathrm{H} 2 \mathrm{O} 2$ production, oxidative stress, and $\mathrm{H} 2 \mathrm{O} 2$-metabolizing enzymes. Plant Physiol., 115:137-149.

[40] M. Schwarz (1985). Antioxidan systems and plant responses to the environment . In: Simiroff N ed. Enviroment and plant metabolism.

[41] T. Senaratna, D. Touchell, E. Bunn, K. Dixon ( 2000). Acetyl salicylic acid (Asperrin ) and salicylic acid induce multiple stress tolerance in bean and tomato plants. Plant Growth Regul.30,157-161.

[42] S. Shabala, A. Mackay (2011). Ion transport in halophytes. In Kader JC, Delseny M (eds) Advances in botanical resea rch, Elsevier, Amsterdam, 57:151-199

[43] J. Song, X. Ding, G. Feng, F. Zhang (2006) Nutritional and osmotic roles of nitrate in a euhalophyte and a xerophyte in saline conditions. New Phytol 171:357-366

[44] R. G. D. Steel, and J. H. Torrie.(1983). Principles and Procedures of Statistics. A Biometrical Approach. Mc Graw Hill, Book Inc., New York, USA. Pp 633.

[45] FH. Witham, BF. Blaydes, RM. Devlin (1971). Experiments in plant physiology, Van Nostrand Reinhold, New York, USA, 1971, pp 167-200

[46] N. Yalpani, AJ . Enyedi, J. Leon, I. Raskin (1994) .Ultraviolet light and ozone stimulate accumulation of salicylic acid, pathogenesis-related proteins and virus resistance in tobacco. Planta 193: 372-376.

[47] JK. Zhu. (2001). Plant salt tolerance. Trends Plant Sci 2001(6):66-71 